\title{
Mechanisms and risks of joint control of nitrogen and phosphorus through sediment capping technology in a pilot-scale study
}

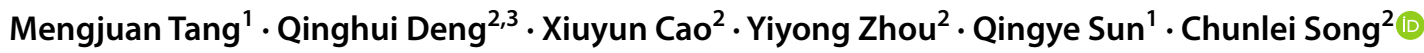

Received: 29 December 2020 / Accepted: 23 May 2021 / Published online: 28 May 2021

(c) The Author(s), under exclusive licence to Springer-Verlag GmbH Germany, part of Springer Nature 2021

\begin{abstract}
Purpose Nitrogen $(\mathrm{N})$ and phosphorus $(\mathrm{P})$ are the key elements leading to eutrophication, and it is important to jointly control $\mathrm{N}$ and $\mathrm{P}$ release from sediments into the water column.

Methods Different mixed materials including P sorbent, natural organic carbon (C), and an oxidizing agent were applied in a 1-year pilot-scale experiment.

Results The addition of iron-rich (IR) clay and Phoslock agent promoted the formation of iron bound $\mathrm{P}(\mathrm{Fe}(\mathrm{OOH}) \sim \mathrm{P})$ and calcium bound $\mathrm{P}\left(\mathrm{CaCO}_{3} \sim \mathrm{P}\right)$ in sediments, respectively. IR clay offered more advantages in immobilization of phosphorus as refractory $\mathrm{P}$, and the Phoslock agent more effectively reduced the risk of $\mathrm{P}$ release into water, which was expressed as a low equilibrium $\mathrm{P}$ concentration $\left(\mathrm{EPC}_{0}\right)$. Mixtures of sugarcane $(\mathrm{SU})$ detritus and IR clay exhibited high carbohydrate (CHO) contents, which further fuelled both denitrification and dissimilatory nitrate reduction to ammonium (DNRA). This indicated that the SU dosage should be controlled to avoid DNRA over denitrification. Attention should be given to the fact that $\mathrm{SU}$ introduction significantly promoted the generation of an anaerobic state, leading to the desorption and release of $\mathrm{Fe}(\mathrm{OOH}) \sim \mathrm{P}$, which could be alleviated by using Oxone. Multienzyme activity analysis showed that $\mathrm{P}$ and $\mathrm{N}$ transformation shifted from $\mathrm{P}$ desorption to organic $\mathrm{P}$ hydrolysis and from ammonification to denitrification and DNRA, respectively. Conclusion We recommend the use of $\mathrm{P}$ sorbent and organic $\mathrm{C}$ combined with oxidizing agents as effective mixed materials for sediment remediation, which could enhance $\mathrm{P}$ adsorption and provide electron donors for denitrification, while also avoiding the generation of anoxia.
\end{abstract}

Keywords Phosphorus sorption $\cdot$ Denitrification $\cdot$ Sediment remediation $\cdot$ DNRA

\section{Introduction}

Eutrophication has become a worldwide environmental problem and a threat to humanity, and it is partly caused by excessive nutrients especially phosphorus $(\mathrm{P})$ and nitrogen

Responsible editor: Haihan Zhang

Chunlei Song

clsong@ihb.ac.cn

Mengjuan Tang

ttangmj@163.com

Qinghui Deng

dengqinghui@ihb.ac.cn

Xiuyun Cao

caoxy@ihb.ac.cn

Yiyong Zhou

zhouyy@ihb.ac.cn
(N) (Paerl et al. 2011; Schmidt et al. 2013; Schindler et al. 2016; Li et al. 2021). However, some efforts to control inputs of external nutrients (e.g., by controlling the direct discharge of domestic sewage, industrial wastewater and agricultural sewage) do not fundamentally solve the problem. Because sediment plays the role of a nutrient sink and source, it releases nutrients to the water column when relevant

Qingye Sun

sunqingye@ahu.edu.cn

1 Anhui University, Hefei 230601, People's Republic of China

2 Key Laboratory of Algal Biology, State Key Laboratory of Freshwater Ecology and Biotechnology, Institute of Hydrobiology, Chinese Academy of Sciences, Wuhan 430072, People's Republic of China

3 University of Chinese Academy of Sciences, Beijing 100039, People's Republic of China 
environmental factors change (Søndergaard et al. 2003; Gu et al. 2019; Lee et al. 2019). For example, the release of $P$ is affected by temperature and levels of dissolved oxygen (Jiang et al. 2008). Additionally, factors such as the rates of organic matter deposition and sediment accumulation drive $\mathrm{N}$ release (Cornwell and Owens 2011).

To decrease the internal loading of nutrients in sediments and the risk of nutrient release, various remediation technologies have been developed. These methods mainly include dredging, in situ capping, in situ chemical applications (e.g., injecting $\mathrm{Fe}, \mathrm{Ca}$, or $\mathrm{Al}$-based agents) and bioremediation (e.g., microorganism strengthening) (Jiao et al. 2011; Liu et al. 2014; Alvarado et al. 2020; Hu et al. 2020; Lin et al. 2020; Rochera et al. 2020). These techniques all exhibited results in laboratory or field sediment remediation experiments. For example, it was observed that mobile $\mathrm{P}$ in sediments was effectively reduced by using the thin-layer capping composed of novel materials (Yin and Kong 2015; $\mathrm{Gu}$ et al. 2017). Additionally, P was reduced efficiently by chemical precipitation caused by addition of an aluminum salt (Auvray et al. 2006). In addition to this, an integrated bioremediation method also controlled $\mathrm{P}$ release and improved aquaculture eutrophication (Wang et al. 2019). Each of the above methods has its own advantages and disadvantages. Compared with the others, the in situ capping method is more effective and easier to implement and has been widely used.

In addition to $\mathrm{P}$ content, $\mathrm{N}$ content is also a crucial factor leading to eutrophication (Xiang et al. 2009). There are several methods aimed at relieving the internal load of $\mathrm{N}$ in sediments. $\mathrm{N}$ release from sediments can be controlled by capping and amendment with iron-modified zeolite (Zhan et al. 2019). In addition, technology involving in situ biochar capping has been applied to control the release of $\mathrm{NH}_{4}{ }^{+}-\mathrm{N}$ in sediments (Zhu et al. 2019). However, methods to control the release of $\mathrm{N}$ are not many as methods to reduce the release of $\mathrm{P}$. The need for joint control of $\mathrm{N}$ and $\mathrm{P}$ is ever more immediate and vital.

Based on this, we designed a pilot-scale experiment to control $\mathrm{N}$ and $\mathrm{P}$ jointly through in situ capping technology intended to achieve simultaneous reductions of the risks of $\mathrm{N}$ and $\mathrm{P}$ release into water bodies. In this study, different materials including iron-rich clay, sugarcane bagasse, Phoslock agent, and Oxone were applied. The levels of $\mathrm{N}$ and $\mathrm{P}$ species, chlorophyll $a(\mathrm{Chl} a$ ) and dissolved organic carbon (DOC) in water samples were determined. The $\mathrm{P}$ fraction and sorption, organic carbon composition, nitrate reduction rates and extracellular enzymatic activities including those of $\beta$-glucosidase (GLU), leucine aminopeptidase (LAP), and alkaline phosphatase (AP), were determined for sediment samples. The aims of this study are to (1) compare the effectiveness and mechanisms of two P sorbents including iron-rich clay and Phoslock agent, (2) test the effect and illuminate the mechanism and potential risk of sugarcane bagasse in controlling $\mathrm{N}$, and (3) propose suggestions for joint control of $\mathrm{N}$ and $\mathrm{P}$ levels.

\section{Materials and methods}

\subsection{Experimental set-up and sampling}

Twelve experimental enclosures were installed in a pond to conduct an in situ pilot-scale experiment. The surface size of the enclosure is $1 \mathrm{~m} \times 1 \mathrm{~m}$, and the height is $2.5 \mathrm{~m}$ which reached from the water surface to the sediment. These enclosures were constructed by waterproof plastic film joined with foam, and this structure could prevent the exchange of water between enclosures and surrounding. Sediments that were collected from the highly eutrophic lake, Lake Chaohu, were mixed with different materials and put into the enclosures. According to this, the twelve enclosures were divided into six groups of duplicates. These six groups were the control treatment $(\mathrm{CT})$, the Phoslock agent treatment $\left(\right.$ Phoslock $\left.^{\circledR}\right)$, the treatment containing Phoslock agent and sugarcane bagasse (Phoslock $\left.{ }^{\circledR}+\mathrm{SU}\right)$, the iron-rich clay treatment (IR), the treatment containing iron-rich clay and sugarcane bagasse $(\mathrm{IR}+\mathrm{SU})$, and the treatment added iron-rich clay and sugarcane bagasse and Oxone (IR+SU+Oxone). Phoslock agent and iron-rich clay were chosen because they can play a role of P sorbent owing to their high P sorption ability, and sugarcane bagasse can provide organic carbon as an electron donor for denitrification while Oxone was used as an oxidizing agent.

The enclosure experiment lasted 1 year (from October 2019 to September 2020, the study was obliged to suspend because of COVID-19 from January to April 2020). Water samples of all groups were collected twice a week and determined nutrients within a day. Surface sediment $(0-10 \mathrm{~cm})$ samples were collected at the beginning of experiment (October 2019) and monthly from the middle of experiment to the end (from May 2020 to September 2020) by a Peterson grab sampler and stored at $4{ }^{\circ} \mathrm{C}$ for analysis within a week.

\subsection{Water sample analysis}

The contents of $\mathrm{N}$ and $\mathrm{P}$ nutrients in water samples were analyzed following national standards (APHA 2012). Total nitrogen (TN) and total phosphorus (TP) were determined in unfiltered water samples. The treated water samples that were filtered through $0.45 \mu \mathrm{m}$ cellulose acetate membranes were tested for soluble nutrients such as total dissolved nitrogen (TDN), ammonium $\left(\mathrm{NH}_{4}{ }^{+}-\mathrm{N}\right)$, nitrite $\left(\mathrm{NO}_{2}{ }^{-}-\mathrm{N}\right)$, nitrate $\left(\mathrm{NO}_{3}{ }^{-} \mathrm{N}\right)$, total dissolved phosphorus (TDP), and soluble reactive phosphorus (SRP). Dissolved organic phosphorus (DOP) was calculated as follows: DOP $=\mathrm{TDP}-\mathrm{SRP}$. Water samples were filtered through GF/C membranes (Whatman, USA) and 
measured by Multi N/C 2100 TOC Analyzer in order to test DOC. For the analysis of Chl $a$, it was extracted with $90 \%$ acetone through GF/C filters (Whatman, USA) and determined by fluorometric method (Yentsch and Menzel 1963).

\subsection{Sediment sample analysis}

Different forms of $\mathrm{C}$ in sediment samples including protein (PRT), carbohydrate (CHO), and lipid (LIP) were analyzed. The analysis of PRT followed Hartree (1972) and is expressed as bovine serum albumin equivalents. $\mathrm{CHO}$ was tested and expressed as glucose equivalents (Gerchakov and Hatcher 1972). The method that is extracting LIP directly with chloroform-methanol was followed to measure LIP (Bligh and Dyer 1959; Marsh and Weinstein 1966).

Different forms of $\mathrm{P}$ in sediment samples which contains $\mathrm{Fe}(\mathrm{OOH}) \sim \mathrm{P}, \mathrm{CaCO}_{3} \sim \mathrm{P}$, acid-soluble organic $\mathrm{P}$ (ASOP), and hot $\mathrm{NaOH}$-extractable organic $\mathrm{P}\left(\mathrm{P}_{\text {alk }}\right)$ were extracted in order (Golterman 1996).

To test sediment $\mathrm{P}$ sorption, the experiment was conducted on the basis of James et al. (1992) and $\mathrm{EPC}_{0}$ were calculated. The parameters of sediment maximum $\mathrm{P}$ adsorbed concentration $\left(\mathrm{Q}_{\max }\right)$ were calculated by Langmuir adsorption isotherm equation (Sakadevan and Bavor 1998).

The activities of GLU, LAP, and AP were determined fluorometrically using the methylumbelliferone labelled substrates L-leucine-4-methylcoumarinylamid, MUG-beta-Dglucopyranoside, and 4-methylumbelliferyl phosphate (Hoppe 1983).

The rates of denitrification and anammox were tested via isotope tracing method with a membrane inlet mass spectrometer (MIMS) (Risgaard-Petersen et al. 2003; Hou et al. 2012), and DNRA rates were measured by OX/MIMS (Yin et al. 2014). Briefly, slurries made by sediments and water at a certain ratio by weight purged by helium for about half an hour and then transfer them into 12-mL gas-tight vials (Labco Exetainers) under a helium atmosphere. After 24-h incubation, ${ }^{15} \mathrm{NO}_{3}{ }^{-}$was added into the vials by a syringe. And then $100 \mu \mathrm{L}$ of saturated $\mathrm{HgCl}_{2}$ were added into the initial samples of DNRA, denitrification, and anammox. The remaining samples incubated for about $8 \mathrm{~h}$ and then preserved with $\mathrm{HgCl}_{2}$ as the final samples. Dissolved nitrogen gas $\left({ }^{29} \mathrm{~N}_{2}\right.$ and $\left.{ }^{30} \mathrm{~N}_{2}\right)$ was tested in half of the final samples for the calculation of anammox and denitrification rates (Nielsen 1992; Risgaard-Petersen et al. 2003) by MIMS. The other half were oxidized with hypobromite iodine solution to transfer the ${ }^{15} \mathrm{NH}_{4}{ }^{+}$produced by DNRA into nitrogen gas $\left({ }^{29} \mathrm{~N}_{2}\right.$ and $\left.{ }^{30} \mathrm{~N}_{2}\right)$ and then DNRA rates were calculated from concentration changes in ${ }^{15} \mathrm{NH}_{4}{ }^{+}$during the incubations.

\subsection{Statistical analysis}

Samples were analyzed in this study with three replicates, and the mean \pm SD of the data was displayed. Average value and standard deviation were analyzed using SPSS Statistics 23. Pearson's correlation coefficients analyzed by SPSS Statistics 23 were also applied in this study to identify the relationships among variables. A statistical significance level was determined within 0.05 among all analyses. Nonlinear regression estimation for the model parameters was conducted by Sigma-Plot 10.0 and dynamic fit wizard function. The concentrations parameters in samples were drawn in the figures by using OriginPro 9.0.

\section{Results and discussion}

The $\mathrm{Fe}(\mathrm{OOH}) \sim \mathrm{P}$ levels in the sample containing IR clay was significantly higher than that in the sample containing Phoslock agent. Compared with the control, the $\mathrm{CaCO}_{3} \sim \mathrm{P}$ concentrations in the treatments containing Phoslock agent and IR clay were significantly higher, especially for the treatments containing Phoslock agent (Fig. 1). This suggested that the addition of IR clay promoted the formation of $\mathrm{Fe}(\mathrm{OOH}) \sim \mathrm{P}$ in sediments, and the addition of Phoslock agent mainly enhanced the formation of $\mathrm{CaCO}_{3} \sim \mathrm{P}$. Analysis of Pearson's correlation revealed that the content of $\mathrm{Fe}(\mathrm{OOH}) \sim \mathrm{P}$ was positively correlated with $\mathrm{EPC}_{0}(P<0.01)$ and that the content of $\mathrm{CaCO}_{3} \sim \mathrm{P}$ was positively correlated with $\mathrm{Q}_{\max } .(P<0.01)$ (Table 1). This implied that the addition of the two P sorbents, and especially Phoslock agent, enhanced $\mathrm{P}$ adsorption capacity and reduced the risk of phosphorus release into water. The $\mathrm{P}$ mobile fraction was transformed into a stable inert $\mathrm{P}$ fraction such as $\mathrm{CaCO}_{3} \sim \mathrm{P}$ when lanthanum-modified materials were used as sorbents to immobilize $\mathrm{P}$ in the surface sediments of shallow eutrophic lakes (Lin et al. 2016; Yin et al. 2020). IR clay minerals were proven to be promising sediment remediation materials useful for $\mathrm{P}$ immobilization due to their strong $\mathrm{P}$ adsorption ability resulting from Fe-P iron binding (Tang et al. 2020). In this study, compared with applications of Phoslock agent and IR treatment, the addition of SU significantly promoted the reduction of $\mathrm{Fe}(\mathrm{OOH}) \sim \mathrm{P}$ levels (Fig. 1), implying that the addition of SU led to the formation of an anaerobic state and further accelerated the desorption and release of $\mathrm{Fe}(\mathrm{OOH}) \sim \mathrm{P}$. The addition of Oxone significantly alleviated the anaerobic state caused by the addition of SU, resulting in higher $\mathrm{Fe}(\mathrm{OOH}) \sim \mathrm{P}$ levels (Fig. 1). The substantial amount of available organic $\mathrm{C}$ in the sediment after addition of sugarcane bagasse fuelled the release of $\mathrm{P}$ from $\mathrm{Fe}(\mathrm{OOH}) \sim \mathrm{P}$, which was induced by anoxia (Tang et al. 2020). The intense biomineralization of organic matter and reduction of $\mathrm{Fe}-\mathrm{Mn}$ oxide levels due to periods of anoxia resulted in transformations of the associated $\mathrm{P}$ fractions (Sudheesh et al. 2017). Also, a positive feedback loop may form among factors related to hypoxia, enhanced $\mathrm{P}$ release, higher primary productivity, and more severe hypoxia, which could accelerate 

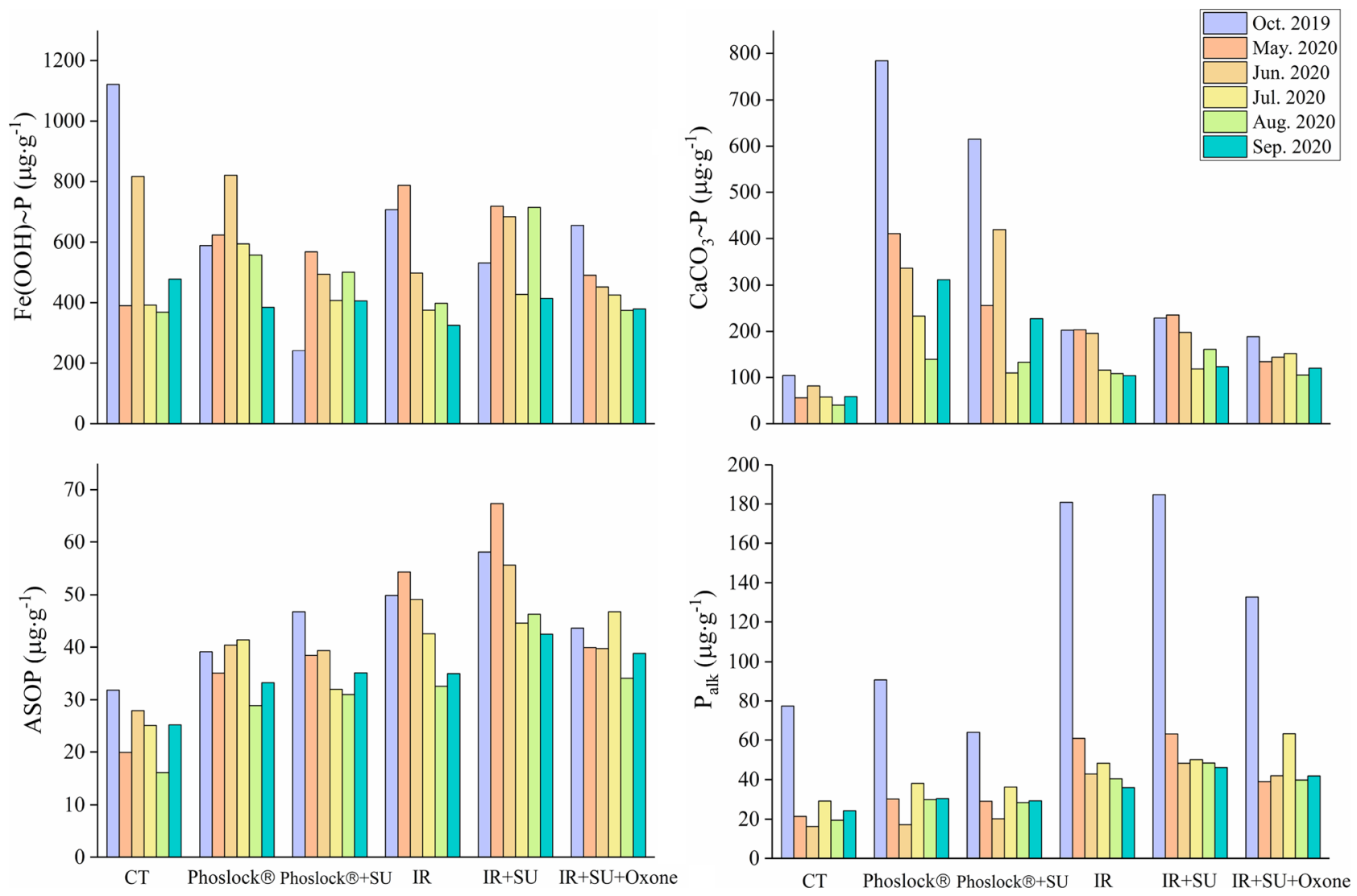

Fig. 1 Different forms of phosphorus (P) in sediments among different treatments

P recycling in large deep reservoirs (Yu et al. 2020). On the other hand, oxygen depletion and increase in labile P levels at the sediment-water interface caused by the decomposition of the deposited algal biomass can be substantially eliminated by capping with oxygen-carrying materials (Zhang et al. 2020). Hence, we suggest that $P$ adsorbent material and organic $\mathrm{C}$ combined with oxidizing agent should be used as an effective mixed material for sediment remediation, which would not only increase $\mathrm{P}$ adsorption and provide electron donor for denitrification but also avoid the generation of anoxia.

It should be noted that the ASOP and $\mathrm{P}_{\text {alk }}$ contents in the treatments containing IR clay were significantly increased, especially $\mathrm{P}_{\text {alk }}$ (Fig. 1), which indicated that IR clay may contain special components that promote the formation of refractory P. Even though the relevant mechanism is not clear, IR clay was more conducive to $\mathrm{P}$ immobilization. Moreover, the addition of IR clay and Phoslock agent significantly reduced $\mathrm{EPC}_{0}$ and increased $\mathrm{Q}_{\max }$ values, especially in samples treated with Phoslock agent (Fig. 2), which indicated the reduced risk of $P$ release into water bodies and the enhanced capacity for $\mathrm{P}$ adsorption. Additionally, an increased maximum adsorption capacity and decreased $\mathrm{EPC}_{0}$ in surface sediments were observed in sediments amended with a calcium peroxide material (Zhou et al. 2020) and zirconium-modified zeolite (Yang et al. 2014), which was favorable for P adsorption and immobilization. Estimates of $\mathrm{EPC}_{0}$ indicated that all P-sorbing products (including "red ochre", "black ochre", "gypsum", "sander dust", "mag dust", "vermiculite", and Phoslock), with the exception of "gypsum", were capable of reducing SRP concentrations in water (Spears et al. 2013). Therefore, addition of IR clay and Phoslock agent promoted phosphorus adsorption and reduced the risk of phosphorus release. IR clay offers more advantages in phosphorus adsorption, and Phoslock agent can more effectively reduce the risk of phosphorus release into water.

Basically, the added materials had little effect on the organic $\mathrm{C}$ contents in sediment. The $\mathrm{CHO}$ levels in the samples amended with IR clay and SU were slightly higher than those in other samples and gradually decreased with time. The addition of materials had no effect on the PRT content, which showed little change during the entire experiment. LIP decreased gradually with time in most treatments (Fig. 3). The anammox process was insignificant in all treatments. Denitrification rates resulting from treatments with added materials were significantly increased relative to those of the control, and at the same time, DNRA rates were also enhanced, especially in samples amended with IR clay and SU (Fig. 4). The 


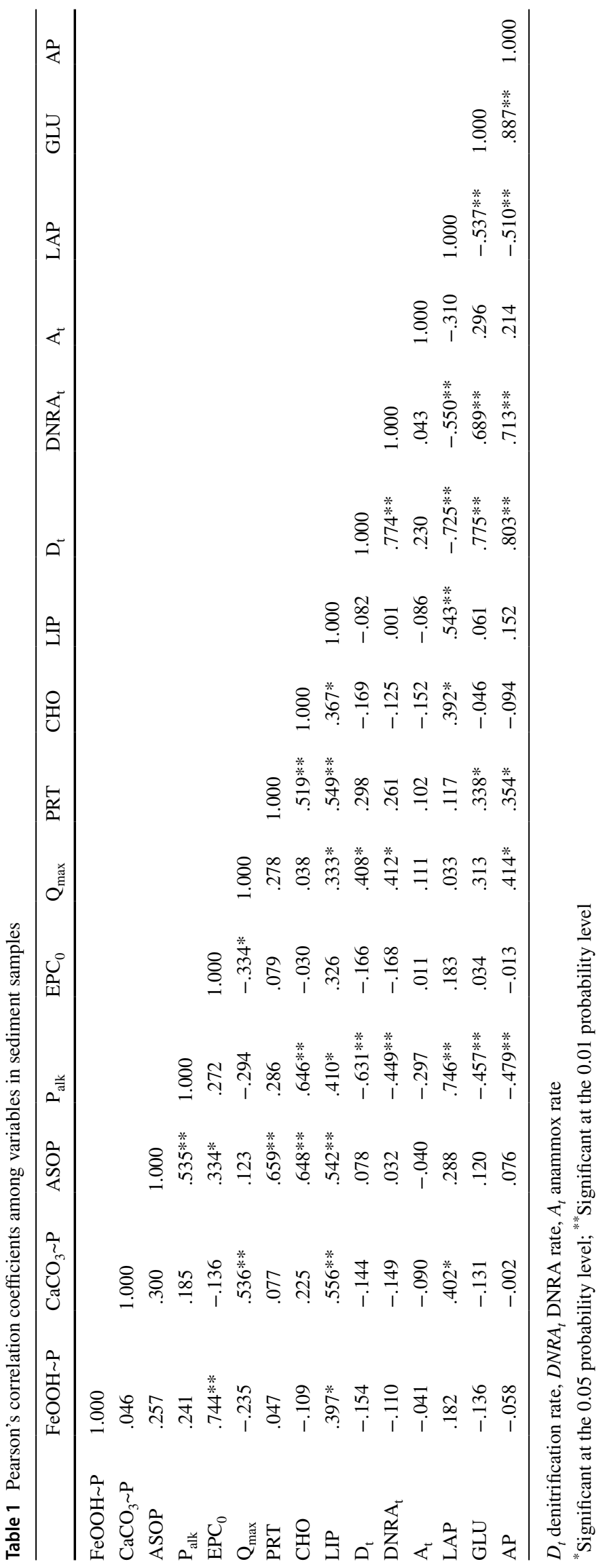


Fig. 2 The parameters of phosphorus $(\mathrm{P})$ sorption in sediments among different treatments
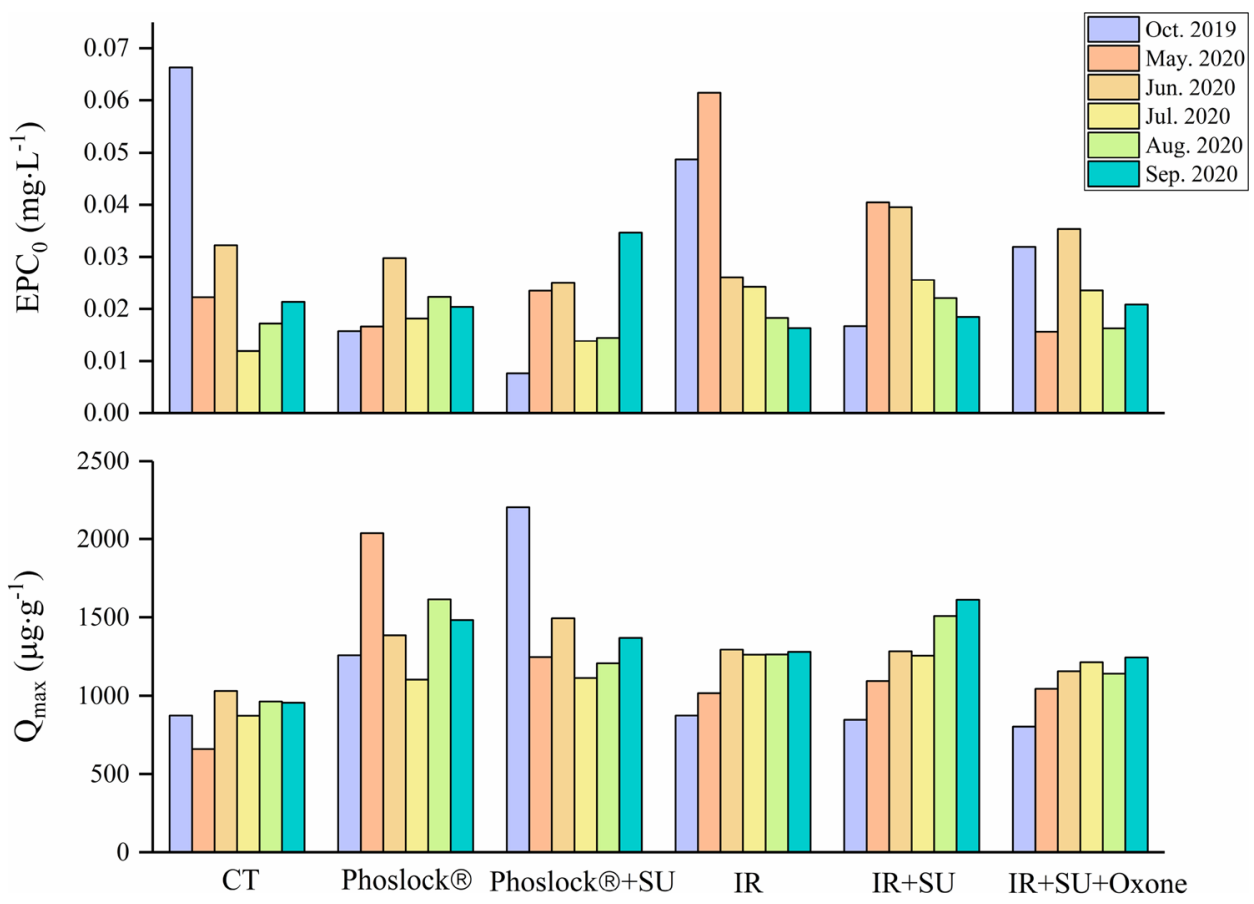

DNRA rate was significantly positively correlated with the denitrification rate $(P<0.01)$ (Table 1$)$. It was deduced that both Phoslock agent and IR clay contained electron donors to promote denitrification. It has been proven that $\mathrm{N}$ losses via denitrification were high in soils containing high clay contents (Van der Salm et al. 2007). Phoslock agent had a positive influence on denitrification, indicating its substantial denitrification capacity (Lin et al. 2016). In addition, the addition of
IR clay and Phoslock agent changed the community structure of denitrifying microorganisms (Ding et al. 2012), which may be another reason for the increased denitrification rate. The mixture of IR clay and SU provided more electron donors, which triggered the DNRA process. This was consistent with the higher $\mathrm{CHO}$ level in the sample modified with IR clay and SU (Fig. 3). High organic C content might favor DNRA over denitrification and subsequently sustain cyanobacterial
Fig. 3 Comparison of carbohydrate $(\mathrm{CHO})$, protein $(\mathrm{PRT})$, and lipid (LIP) in sediments among different treatment
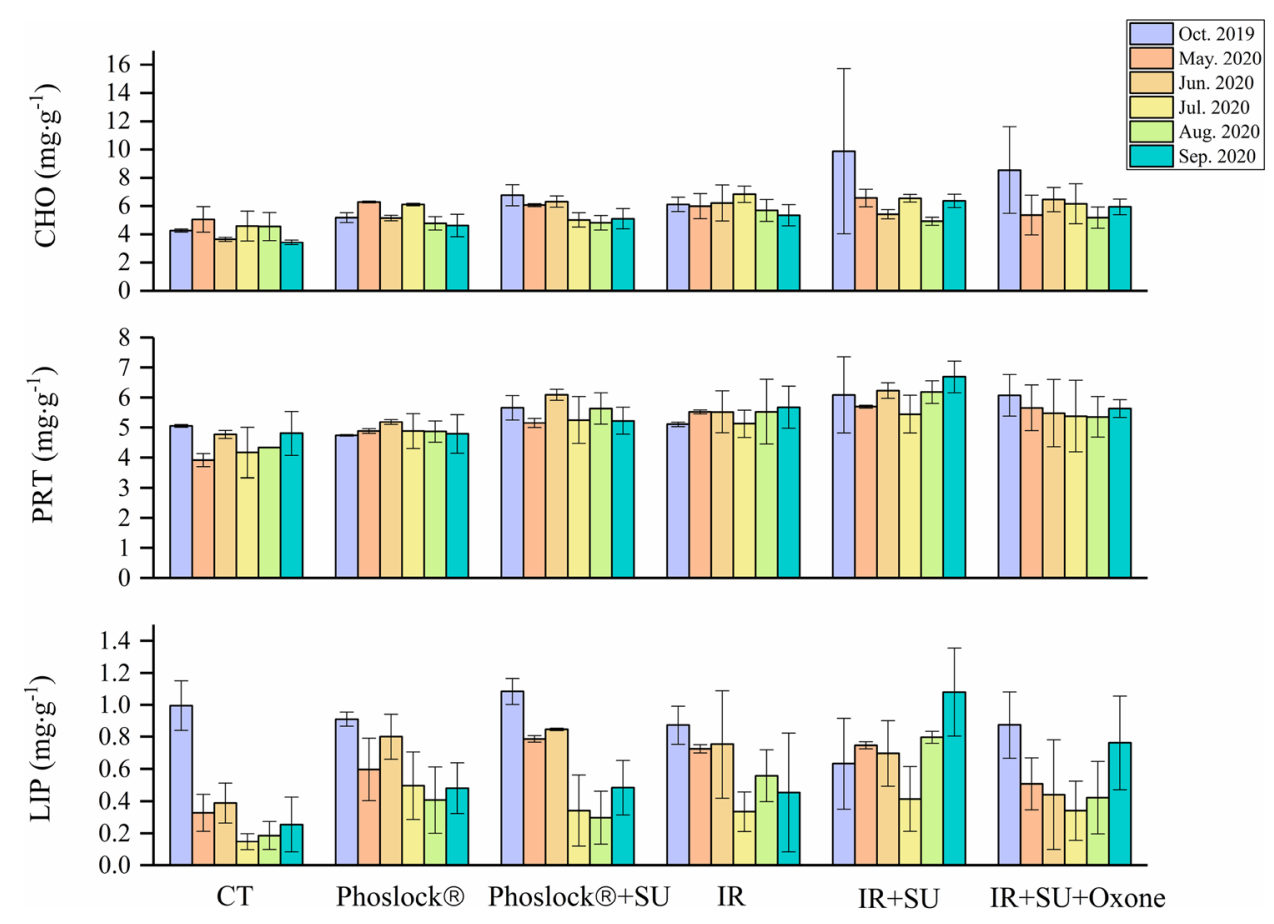
Fig. 4 Nitrate reduction rates in sediments among different treatments

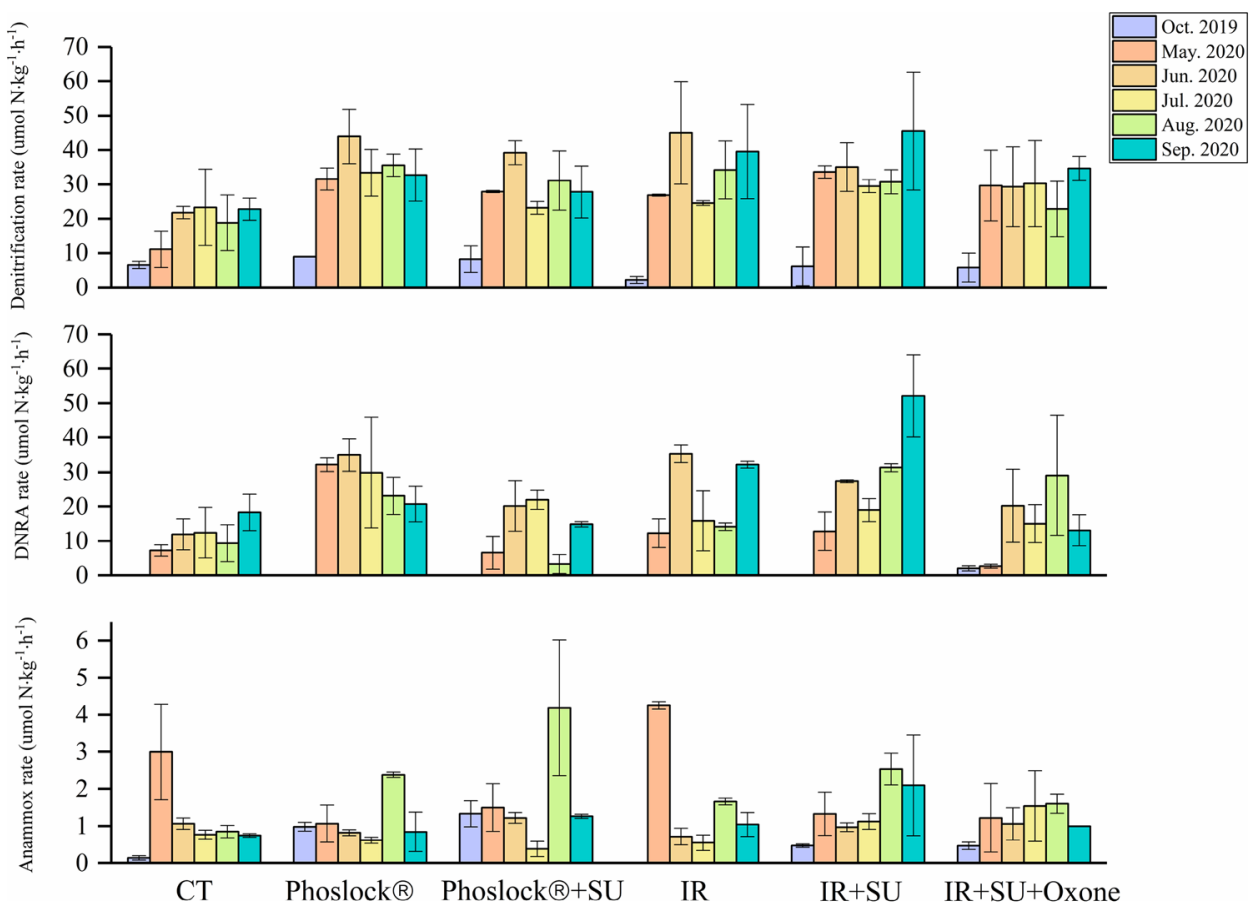

blooms (Jiang et al. 2020). Therefore, Phoslock agent and IR clay, and especially IR clay, promoted the removal of $\mathrm{N}$ through denitrification in sediments, but excessive introduction of electron donors, such as with SU addition might lead to DNRA competition over denitrification.

Multienzyme activity analysis showed that the microbial mediated degradation of organic $\mathrm{C}$ and $\mathrm{P}$ in the sediment expressed as GLU and AP respectively, substantially increased with time after the addition of remediation materials (Fig. 5). This indicated that the addition of sediment remediation materials promoted the utilization and degradation of organic $\mathrm{C}$ by microorganisms, which further led to activation of electron transport processes, such as the denitrification and DNRA processes (Fig. 4). Correlation
Fig. 5 The extracellular enzymatic activities of leucine aminopeptidase (LAP), $\beta$-glucosidase (GLU), and alkaline phosphatase (AP) in sediments among different treatments
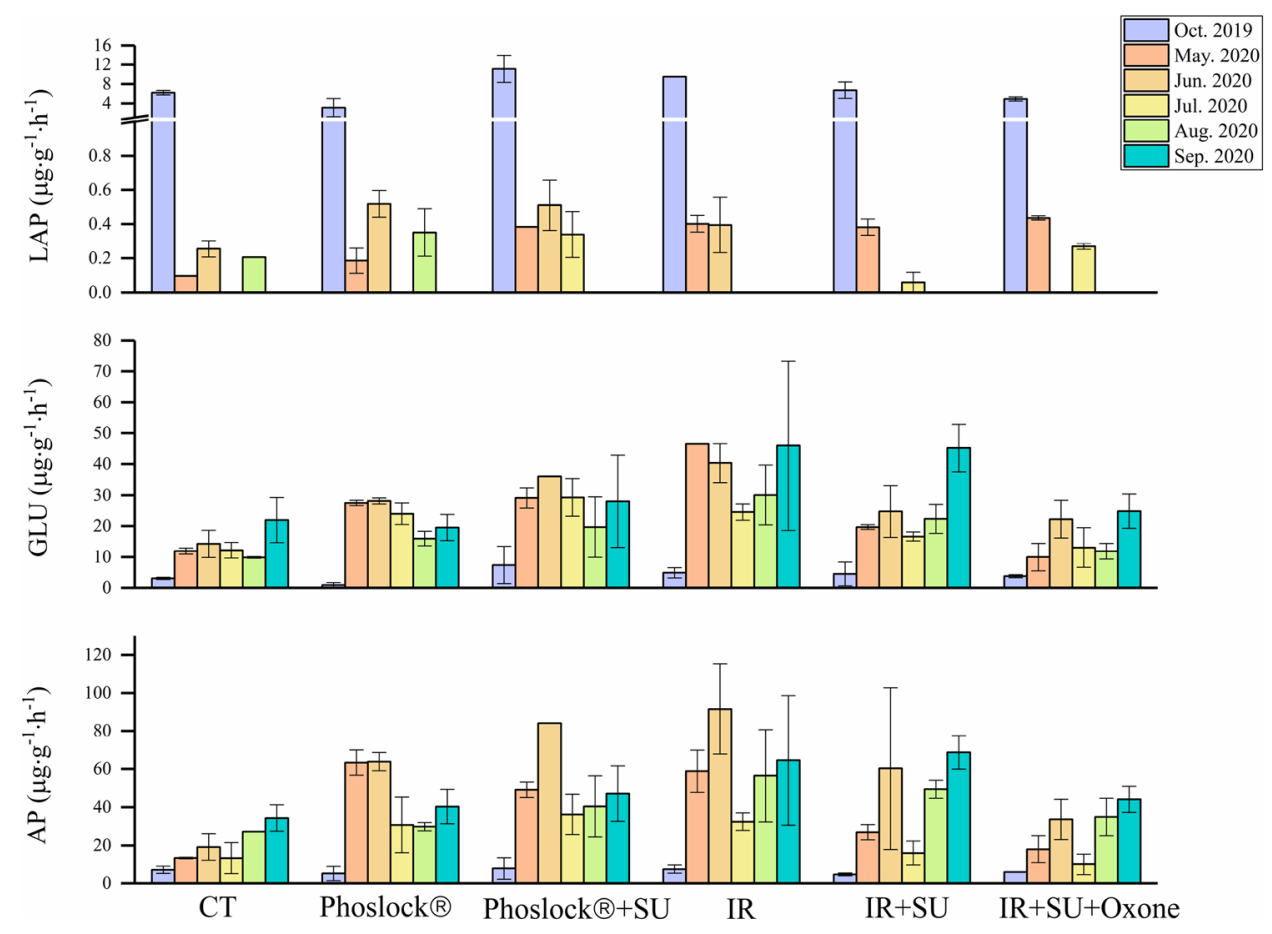

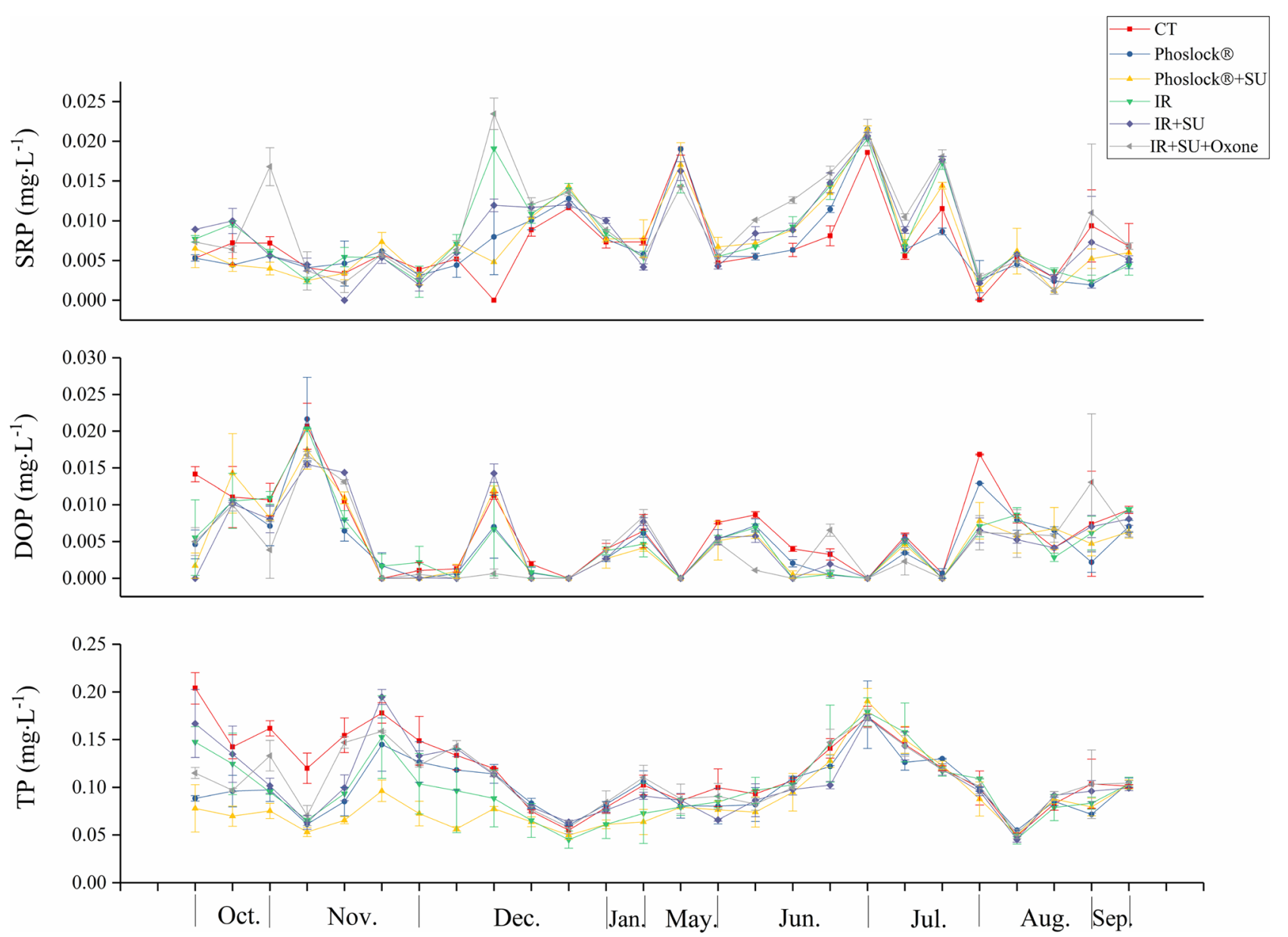

Fig. 6 Concentrations of soluble reactive phosphorus (SRP), dissolved organic phosphorus (DOP), and total phosphorus (TP) in water column among different treatments

analysis also confirmed this result which revealed that the extracellular enzymatic activities of GLU and AP were positively correlated with denitrification rates and DNRA rates $(P<0.01)$ (Table 1). On the other hand, the added materials greatly enhanced $P$ adsorption capability, causing the $P$ regeneration process to shift from $P$ desorption o to the hydrolysis of organic P. At the same time, the LAP activity was very low after adding the remediation materials, indicating the diminished ability of organic $\mathrm{N}$ to effect hydrolysis, which stood in contrast with the high denitrification and DNRA rates (Fig. 4). The extracellular enzymatic activities of LAP showed a significant negative correlation with denitrification rates $(P<0.01)$ and DNRA rates $(P<0.01)$ according to the correlation analysis (Table 1$)$. This reflected the fact that the processes for $\mathrm{N}$ transformation gradually changed from ammonification to denitrification and DNRA. Redundancy analysis (RDA) showed that succession of the bacterial community may accelerate the transformation of nutrients mediated by microorganisms in the sediment after remediation (Zhang et al. 2019). Therefore, the addition of sediment remediation materials not only acted directly on nutrient levels by adsorption but also changed the microbial activity and community structure, leading to shifts in nutrient transformation processes. Thus, attention should be given to the fact that the addition of sediment remediation materials intensified the nutrient regeneration process mediated by microorganisms.

SRP and DOP in water bodies showed low levels and no significant differences among all treatments. At the early stages of the experiment, TP was highest in the control, and the lowest in the treatments containing Phoslock agent, Phoslock agent + SU and IR clay. There was no significant difference in TP in any treatment at the later stages of the experiment (Fig. 6). $\mathrm{NH}_{4}{ }^{+} \mathrm{N}$ was at a lower level in the control, and higher in the treatment amended with IR clay $+\mathrm{SU}$ (Fig. 7), which was consistent with the DNRA rate (Fig. 4), indicating that the addition of IR clay and SU accelerated the DNRA rate in sediment and the accumulation of $\mathrm{NH}_{4}{ }^{+}-\mathrm{N}$ in water bodies. No significant difference was recorded for $\mathrm{NO}_{2}^{-}-\mathrm{N}, \mathrm{NO}_{3}^{-}-\mathrm{N}$ or DOC among the treatments (Figs. 7 and 


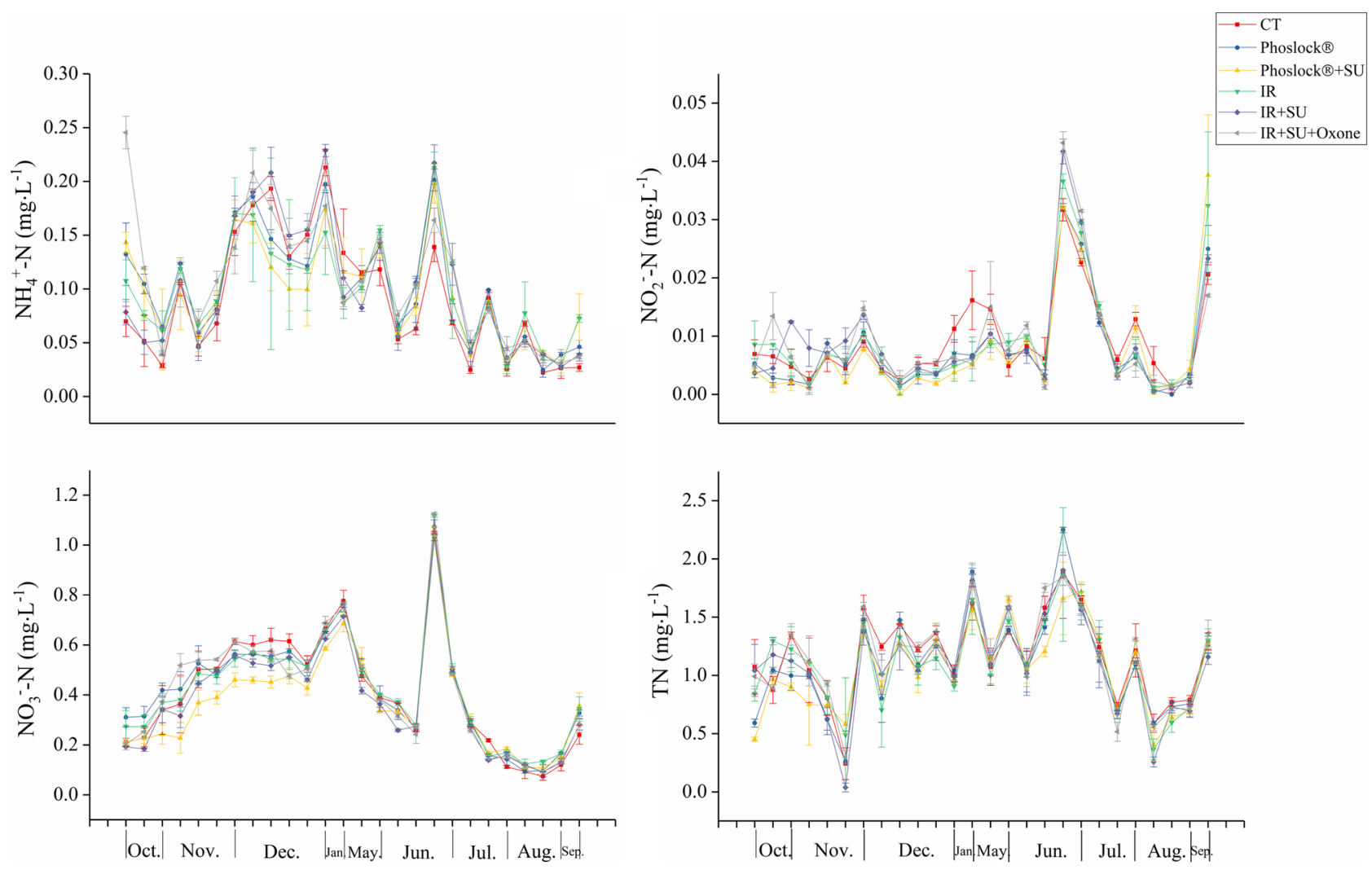

Fig. 7 Concentrations of ammonium $\left(\mathrm{NH}_{4}{ }^{-}-\mathrm{N}\right)$, nitrite $\left(\mathrm{NO}_{2}{ }^{-}-\mathrm{N}\right)$, nitrate $\left(\mathrm{NO}_{3}{ }^{-}-\mathrm{N}\right)$ and total nitrogen $(\mathrm{TN})$ in water column among different treatments

8). Chl $a$ concentration in the treatments containing Phoslock agent was the lowest, but there was no significant difference compared with the treatments containing IR clay (Fig. 8). In considering TP levels in water bodies (Fig. 6), the effects of IR clay amendment on TP and Chl $a$ were comparable to those of Phoslock agent.
Fig. 8 Concentrations of dissolved organic carbon (DOC) and Chl $a$ in water column among different treatments
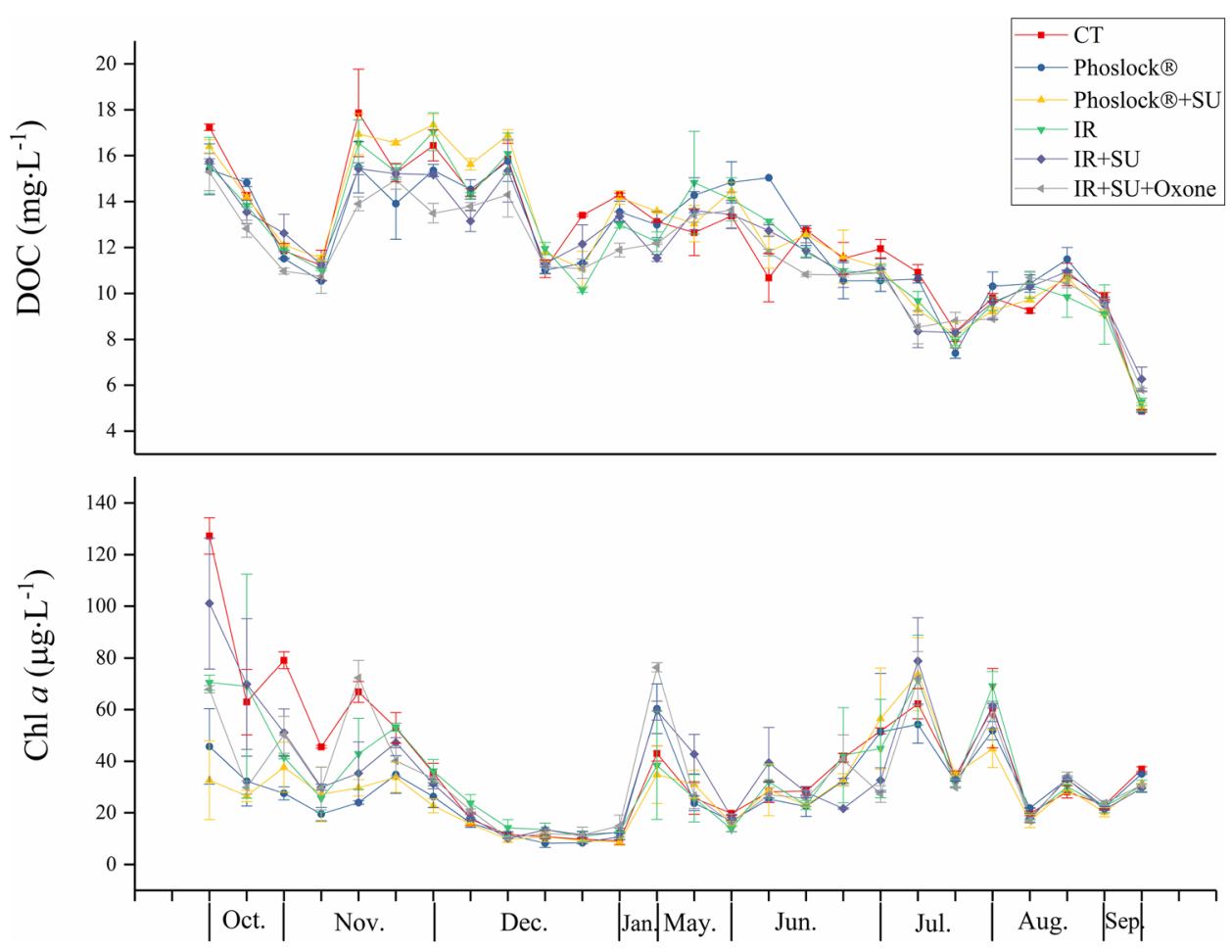


\section{Conclusions}

The addition of IR clay and Phoslock agent promoted the formation of $\mathrm{Fe}(\mathrm{OOH}) \sim \mathrm{P}$ and $\mathrm{CaCO}_{3} \sim \mathrm{P}$ in sediments, respectively. IR clay offered more advantages in phosphorus adsorption, and Phoslock agent can more effectively reduced the risk of phosphorus release into water. There was no significant difference between IR clay and Phoslock agent in controlling the release of phosphorus from sediments into water bodies. In addition, SU addition provided more electron donors for denitrification and promoted the removal of $\mathrm{N}$ from sediments, but excessive introduction of electron donors might lead to DNRA enhancement over denitrification. Attention should be given to the fact that SU introduction significantly promoted the generation of an anaerobic state; this led to the desorption and release of $\mathrm{Fe}(\mathrm{OOH}) \sim \mathrm{P}$, which was alleviated through amendment with Oxone. Hence, we recommend that $\mathrm{P}$ adsorbent material and organic $\mathrm{C}$ combined with oxidizing agent should be used as an effective mixed material for sediment remediation, which would not only increase $\mathrm{P}$ adsorption and provide electron donors for denitrification but also avoid the generation of anoxia.

Author contribution Material preparation, data collection and analysis were performed by MT and QD. XC, YZ, and QS were responsible for the data analysis. CS contributed to the study design and manuscript correction. All authors read and approved the final manuscript.

Funding This work was supported by the Strategic Priority Research Program of the Chinese Academy of Science (No.XDA23040403), the National Natural Science Foundation of China (41877381; 42077314; 91951119), the Major Science and Technology Program for Water Pollution Control and Treatment (2017ZX07603), and State Key Laboratory of Freshwater Ecology and Biotechnology (2019FBZ01).

\section{Declarations}

Conflict of interest The authors declare no competing interests.

\section{References}

Alvarado JN, Hong SH, Lee CG, Park SJ (2020) Comparison of capping and mixing of calcined dolomite and zeolite for interrupting the release of nutrients from contaminated lake sediment. Environ Sci Pollut Res 27:15045-15056. https://doi.org/10.1007/ s11356-020-08058-y

APHA (2012) Standard methods for the examination of water and wastewater (22nd ed.). American Public Health Association (APHA), Washington, DC, USA

Auvray F, van Hullebusch ED, Deluchat V, Baudu M (2006) Laboratory investigation of the phosphorus removal (SRP and TP) from eutrophic lake water treated with aluminium. Water Res 40:27132719. https://doi.org/10.1016/j.watres.2006.04.042

Bligh EG, Dyer WJ (1959) A rapid method of total lipid extraction and purification. Can J Biochem Physiol 37(8):911-917
Cornwell JC, Owens MS (2011) Quantifying sediment nitrogen releases associated with estuarine dredging. Aquat Geochem 17(4-5):499-517. https://doi.org/10.1007/s10498-011-9139-y

Ding YQ, Qin BQ, Xu H, Dong BL, Brookes JD (2012) Comparison of efficacy of two P-inactivation agents on sediments from different regions of Lake Taihu: sediment core incubations. Fundam Appl Limnol 181(4):271-281. https://doi.org/10.1127/1863-9135/2012/0297

Gerchakov SM, Hatcher PG (1972) Improved technique for analysis of carbohydrates in sediment. Limnol Oceanogr 17(6):938-943. https://doi.org/10.4319/lo.1972.17.6.0938

Golterman HL (1996) Fractionation of sediment phosphate with chelating compounds: A simplification, and comparison with other methods. Hydrobiologia 335(1):87-95. https://doi.org/10.1007/BF00013687

Gu BW, Hong SH, Lee CG, Park SJ (2019) The feasibility of using bentonite, illite, and zeolite as capping materials to stabilize nutrients and interrupt their release from contaminated lake sediments. Chemosphere 219:217-226. https://doi.org/10.1016/j. chemosphere.2018.12.021

Gu BW, Lee CG, Lee TG, Park SJ (2017) Evaluation of sediment capping with activated carbon and nonwoven fabric mat to interrupt nutrient release from lake sediments. Sci Total Environ 599600:413-421. https://doi.org/10.1016/j.scitotenv.2017.04.212

Hartree EF (1972) Determination of protein: a modification of the Lowry method that gives a linear photometric response. Anal Biochem 48(2):422-427. https://doi.org/10.1016/0003-2697(72)90094-2

Hoppe HG (1983) Significance of exoenzymatic activities in the ecology of brackish water: measurements by means of methylumbelliferylsubstrates. Mar Ecol Prog Ser 11:299-308. https://doi.org/10.3354/ meps011299

Hou L, Liu M, Carini SA, Gardner WS (2012) Transformation and fate of nitrate near the sediment-water interface of Copano Bay. Cont Shelf Res 35:86-94. https://doi.org/10.1016/j.csr.2012.01.004

Hu Z, Deng S, Li D, Guan D, Xie B, Zhang C, Li P, Yao H (2020) Application of iron $[\mathrm{Fe}(0)]$-rich substrate as a novel capping material for efficient simultaneous remediation of contaminated sediments and the overlying water body. Sci Total Environ 748:141596. https://doi.org/10.1016/j.scitotenv.2020.141596

James BR, Rabenhorst MC, Frigon GA (1992) Phosphorus sorption by peat and sand amended with iron-oxides or steel wool. Water Environ Res 64:699-705. https://doi.org/10.2175/wer.64.5.6

Jiang X, Gao G, Zhang L, Tang X, Cai J (2020) Role of algal accumulations on the partitioning between $\mathrm{N}_{2}$ production and dissimilatory nitrate reduction to ammonium in eutrophic lakes. Water Res 183:116075. https://doi.org/10.1016/j.watres.2020.116075

Jiang X, Jin X, Yao Y, Li L, Wu F (2008) Effects of biological activity, light, temperature and oxygen on phosphorus release processes at the sediment and water interface of Taihu Lake, China. Water Res 42:2251-2259. https://doi.org/10.1016/j.watres.2007.12.003

Jiao Y, Zhao Q, Jin W, Hao X, You S (2011) Bioaugmentation of a biological contact oxidation ditch with indigenous nitrifying bacteria for in situ remediation of nitrogen-rich stream water. Bioresour Technol 102:990-995. https://doi.org/10.1016/j.biortech.2010.09.061

Lee HW, Lee YS, Kim J, Lim KJ, Choi JH (2019) Contribution of internal nutrients loading on the water quality of a reservoir. Water 11:1409. https://doi.org/10.3390/w11071409

Li H, Song C, Yang L, Qin H, Cao X, Zhou Y (2021) Nutrients regeneration pathway, release potential, transformation pattern and algal utilization strategies jointly drove cyanobacterial growth and their succession. J Environ Sci 103:255-267. https://doi.org/10.1016/j. jes.2020.11.010

Lin J, Zhao Y, Zhan Y, Wang Y (2020) Control of internal phosphorus release from sediments using magnetic lanthanum/iron-modified bentonite as active capping material. Environ Pollut 264:114809. https://doi.org/10.1016/j.envpol.2020.114809

Lin J, Zhong YF, Fan H, Song CF, Yu C, Gao Y, Xiong X, Wu CX, Liu JT (2016) Chemical treatment of contaminated sediment for 
phosphorus control and subsequent effects on ammonia-oxidizing and ammonia-denitrifying microorganisms and on submerged macrophyte revegetation. Environ Sci Pollut Res 24:1007-1018. https://doi.org/10.1007/s11356-016-7828-1

Liu T, Yuan J, Dong W, Wu H, Wang H (2014) Effects on inorganic nitrogen compounds release of contaminated sediment treatment with in situ calcium nitrate injection. Environ Sci Pollut Res 22:1250-1260. https://doi.org/10.1007/s11356-014-3421-7

Marsh JB, Weinstein DB (1966) Simple charring method for determination of lipids. J Lipid Res 7(4):574-576

Nielsen LP (1992) Denitrification in sediment determined from nitrogen isotope pairing. FEMS Microbiol Lett 86(4):357-362. https:// doi.org/10.1111/j.1574-6968.1992.tb04828.x

Paerl HW, Xu H, McCarthy MJ, Zhu G, Qin B, Li Y, Gardner WS (2011) Controlling harmful cyanobacterial blooms in a hypereutrophic lake (Lake Taihu, China): the need for a dual nutrient (N \& P) management strategy. Water Res 45:1973-1983. https:// doi.org/10.1016/j.watres.2010.09.018

Risgaard-Petersen N, Nielsen LP, Rysgaard S, Dalsgaard T, Meyer RL (2003) Application of the isotope pairing technique in sediments where anammox and denitrification coexist. Limnol Oceanogr Meth 1:63-73. https://doi.org/10.4319/lom.2011.1.63

Rochera C, Picazo A, Murueta N, Camacho A (2020) In situ bioremediation techniques to reduce total organic matter oversaturation of fluvial sediments: an experimental study. Appl Sci 10:4308. https://doi.org/10.3390/app10124308

Sakadevan K, Bavor HJ (1998) Phosphate adsorption characteristics of soils, slags and zeolite to be used as substrates in constructed wetland systems. Water Res 32(2):393-399. https://doi.org/10. 1016/S0043-1354(97)00271-6

Schindler DW, Carpenter SR, Chapra SC, Hecky RE, Orihel DM (2016) Reducing phosphorus to curb lake eutrophication is a success. Environ Sci Technol 50:8923-8929. https://doi.org/10.1021/acs. est.6b02204

Schmidt JR, Shaskus M, Estenik JF, Oesch C, Khidekel R, Boyer GL (2013) Variations in the microcystin content of different fish species collected from a eutrophic lake. Toxins 5:992-1009. https:// doi.org/10.3390/toxins5050992

Søndergaard M, Jensen JP, Jeppesen E (2003) Role of sediment and internal loading of phosphorus in shallow lakes. Hydrobiologia 506(13):135-145. https://doi.org/10.1023/B:HYDR.0000008611.12704.dd

Spears BM, Meis S, Anderson A, Kellou M (2013) Comparison of phosphorus $(\mathrm{P})$ removal properties of materials proposed for the control of sediment P release in UK lakes. Sci Total Environ 442:103-110. https://doi.org/10.1016/j.scitotenv.2012.09.066

Sudheesh V, Movitha M, Hatha AAM, Renjith KR, Resmi P, Rahiman M, Nair SM (2017) Effects of seasonal anoxia on the distribution of phosphorus fractions in the surface sediments of southeastern Arabian Sea shelf. Cont Shelf Res 150:57-64. https://doi.org/10. 1016/j.csr.2017.09.011

Tang MJ, Deng QH, Li XW, Cao XY, Zhang ZM, Zhou YY, Sun QY, Song CL (2020) The effect of natural materials used as sediment remediation on phosphorus and nitrogen control in a mesocosm. Environ Sci Eur 32:90. https://doi.org/10.1186/ s12302-020-00366-x

Van der Salm C, Dolfing J, Heinen M, Velthof GL (2007) Estimation of nitrogen losses via denitrification from a heavy clay soil under grass. Agric Ecosyst Environ 119(3-4):311-319. https://doi.org/ 10.1016/j.agee.2006.07.018
Wang L, Shao X, Xu M, Chen S (2019) Bioremediation of nitrogenand phosphorus-polluted aquaculture sediment by utilizing combined immobilized effective microorganisms and sediment aeration technology. Int J Agric Biol Eng 12:192-201. https://doi.org/ 10.25165/j.ijabe.20191206.4904

Xiang W, Xiao EY, Rengel Z (2009) Phytoremediation facilitates removal of nitrogen and phosphorus from eutrophicated water and release from sediment. Environ Monit Assess 157:277-285. https://doi.org/10.1007/s10661-008-0534-9

Yang M, Lin J, Zhan Y, Zhang H (2014) Adsorption of phosphate from water on lake sediments amended with zirconium-modified zeolites in batch mode. Ecol Eng 71:223-233. https://doi.org/10. 1016/j.ecoleng.2014.07.035

Yentsch CS, Menzel DW (1963) A method for the determination of phytoplankton chlorophyll and phaeophytin by fluorescence. Deep-Sea Res 10:221-231. https://doi.org/10.1016/00117471(63)90358-9

Yin G, Hou L, Liu M, Liu Z, Gardner WS (2014) A novel membrane inlet mass spectrometer method to measure ${ }^{15} \mathrm{NH}_{4}{ }^{+}$for isotopeenrichment experiments in aquatic ecosystems. Environ Sci Technol 48(16):9555-9562. https://doi.org/10.1021/es501261s

Yin H, Kong M (2015) Reduction of sediment internal P-loading from eutrophic lakes using thermally modified calcium-rich attapulgitebased thin-layer cap. J Environ Manage 151:178-185. https://doi. org/10.1016/j.jenvman.2015.01.003

Yin HB, Yang P, Kong M, Li W (2020) Use of lanthanum/aluminum co-modified granulated attapulgite clay as a novel phosphorus $(\mathrm{P})$ sorbent to immobilize $\mathrm{P}$ and stabilize surface sediment in shallow eutrophic lakes. Chem Eng J 385:123395. https://doi.org/10. 1016/j.cej.2019.123395

Yu J, Chen JG, Zeng Y, Lu YT, Chen Q (2020) Carbon and phosphorus transformation during the deposition of particulate matter in the large deep reservoir. J Environ Manage 265:110514. https://doi. org/10.1016/j.jenvman.2020.110514

Zhan Y, Yu Y, Lin J, Wu X, Wang Y, Zhao Y (2019) Simultaneous control of nitrogen and phosphorus release from sediments using iron-modified zeolite as capping and amendment materials. J Environ Manage 249:109369. https://doi.org/10.1016/j.jenvman.2019. 109369

Zhang H, Chen J, Han M, An W, Yu JW (2020) Anoxia remediation and internal loading modulation in eutrophic lakes using geoengineering method based on oxygen nanobubbles. Sci Total Environ 714:136766. https://doi.org/10.1016/j.scitotenv.2020.136766

Zhang J, Tang Y, Kou ZG, Teng X, Cai W, Hu J (2019) Shift of sediments bacterial community in the black-odor urban river during in situ remediation by comprehensive measures. Water 11(10):2129. https://doi.org/10.3390/w11102129

Zhou J, Li D, Zhao Z, Song X, Huang Y, Yang JJ (2020) Phosphorus immobilization by the surface sediments under the capping with new calcium peroxide material. J Clean Prod 247:119135. https:// doi.org/10.1016/j.jclepro.2019.119135

Zhu Y, Shan B, Huang J, Teasdale PR, Tang W (2019) In situ biochar capping is feasible to control ammonia nitrogen release from sediments evaluated by DGT. Chem Eng J 374:811-821. https://doi. org/10.1016/j.cej.2019.06.007

Publisher's Note Springer Nature remains neutral with regard to jurisdictional claims in published maps and institutional affiliations. 